\title{
John Colet on Law and Liberty
}

\author{
DANIEL T. LOCHMAN
}

Study of reformation theology has drawn increased attention to the contexts
of writers on difficult issues such as free will and predestination. In isolated
passages, substantive differences between writers on such issues may seem
elusive; often, similar interpretations of key scriptural texts obscure import-
ant shifts in focus and emphasis. ${ }^{1}$ One crucial context is the writer's concep-
tion of law in its civil, Hebraic, Mosaic, and Christian forms; discussions of
law, especially important in Western Christianity, focus attention on the
possibility and limit of liberty and therefore on the question of voluntary
action.

John Colet, who died just two years after Luther posted the ninety-five theses, addresses issues concerning human and divine law in commentaries on Paul's epistles and treatises on the mystical body, the sacraments, and Dionysian ontology and ecclesiology. In part Colet's concept of law reflects interests associated with the via moderna and the influence of Augustine's anti-Pelagian tracts. It adumbrates issues central to the reformation, including the terms of God's covenant or pactum, the power of the instrumental grace, and the priority of God's external judgment in justification; and it reflects nominalist interests in the historical continuity of fiducial justification from Abraham to Christ and a view of moral strife that culminates in spiritual perfection. ${ }^{2}$ Colet's views combine the via moderna's emphasis on the interiority of justification with Neoplatonic views of actio drawn from fifteenth-century Italians. These in turn draw on a second, idealistic form of Augustinianism rooted in De civitate dei and De Trinitate and confirmed in the Eastern tradition. This strain particularly values the Neoplatonic principle of unity expressed in figures such as the heavenly city and the corpus of the church, and it provides a rationale for the contingency of multiple and varied beings. ${ }^{3}$ Pragmatically, Colet's theory of law, unlike Luther's, strongly supports the value of canonic law at the expense of its civil counterparts; unlike Thomas More, however, Colet undercuts the value of all law by 
asserting with the via moderna and Luther the need not only for consensus but also for a personal response to God's call.

\section{I}

Erasmus observes that Colet was knowledgeable in both canon and civil law, the former seemingly confirmed by his later service on ecclesiastical courts, the latter, by his service on Henry VIII's Royal Council. ${ }^{4}$ In his writings Colet maintains a traditional view that Christians are liberated from Old Testament legalism by their redemption, but he emphasizes that the power of the Spirit's grace under the new law of faith is instrumental for human action in the ecclesia. He resolves the implicit paradox between liberation and legal restraint by appealing to Augustine's principle of Christian cooperatio in the performance of God's dominating will. At the same time he gives a theological function to rhetorical powers of suasion which, humanists claimed, could move the lapsed passions and will more effectively than reason. ${ }^{5}$

Colet's most detailed discussion of law occurs in one of two commentaries on Paul's epistle to the Romans, the Expositio, in a passage whose emphasis on interior belief links his thought both to Erasmus and Luther. $\mathrm{He}$ describes the historical era of Christianity as a stage in the fulfillment of Abraham's pactum of faith with God; according to the terms of the covenant, faith rooted in fidutia or trust constitutes the prerequisite for fulfilling God's promise to Abraham of a numerous progeny. He distinguishes human from divine law after considering Paul's contrast between Abraham's justice derived from faith and his ceremonial act in circumcision (Rom. 4 : 9-12). Like his friend Erasmus, Colet affirms that external rites must be informed by an internal state of trust if they are to be meritorious. ${ }^{6}$ Abraham's act may fit under the title of "law," yet the physical act applies only to externals, not to the true spiritual law which should determine human action.

In an important digression following this comment, Colet distinguishes absolutely between human and divine law. In so doing, Colet asserts more forcefully than many theologians before and since that the fallen are incapable of reasoning truly unless assisted by grace; human law considered apart from God's rule is deemed corrupt. ${ }^{7}$

Prior to the fall, Colet notes, there existed a single and unified divine order identical to God's will; no gap separated providence from law. At creation, God expressed his law when he "formed all things, gave to each its limit, and fashioned the beautiful order of things" (ExR, IV. 256). Afterwards, he "commanded" (jussit) the heavenly powers to act "holily and incorruptly" 
in order to preserve his honor and conserve the general utility of things: "this law (jus) and divine command (jussum divinum)" were then, says Colet, "universal" (ExR, IV. 256).

The disobedience of the "prince of transgression" (transgressionis princeps), whom Colet variously calls diabolus, criminator, Sathanus, or adversarius, first disturbed this orderly and stable universe. Sin in pride constituted the first "crime" under the divine law (ExR, IV. 256), the first disruption of the unity of God's will, and the divergence of human justice from providence. Placed in paradise to obey God, Adam instead listened to the pleas of the first transgressor and, due to pride and ambition, likewise became a "transgressor of divine law" (ExR, IV. 257). According to Colet, Adam's crime profoundly impaired all human faculties. Mental abilities which, according to Augustine, imaged the Trinity and had formed the basis of medieval and Renaissance discussions of mankind's natural dignity - will, intellect, and memory - were "turned askew" (obliquator) by original sin. ${ }^{8}$ Non-intellective faculties became corrupt; fleshly appetites were inflamed, and sources of corporeal and spiritual pain and death became "infinite," producing a life of misery for all save those elect who felt the compelling attraction of grace (ExR, IV. 257). ${ }^{9}$

In a more sweeping fashion than the mature thought of Luther, Colet classes all laws outside divine law under the heading of the corrupt "law of human nature" (lex humanae naturae). Before Christ the several classes of human law were thoroughly opposed to God: innate law of conscience, "universal law" (jus gentium) of ownership and proprietary rights (the principle of meum et teum), civil or municipal law, common law, and statutes or decrees. Collectively, human law before Christ acted as the "mother of sin" (matris peccati) due to its origin in the corrupt minds of the fallen and its failure to seek justice for the single "community of all" (ExR, IV, 260). These alienating states of morality, civility, and cognition comprise the law of corrupt human nature (lex corruptae naturae hominis), wherein good and evil become inverted: justice becomes injustice, reason becomes subservient to the flesh and libido (ExR, IV. 258-259).

On one hand Colet rejects rationally developed human law in the postlapsarian era, especially justifications like Aquinas' of human law's participation in truths reflected in nature; on the other he affirms the value of divine law before and after the fall, conceding that those corrupted by the fall and unredeemed by Christ may be recalled to justice through God's arbitrary will. ${ }^{10}$ At any point, humanity could have surmounted its fallen state by heeding God's general call observed in nature, despite the latter's corruption 
in its lapsed state. Indeed a few individuals in the Old Testament did respond to the call initiated through God's will: "From the beginning," from Adam, God drew some above the human "flood of iniquity" and into the "pure (liquido) spirit of God." Patriarchs from Adam to Abraham and from Melchisedech to Joseph (cf. Heb. 7, $11: 4-22$ ) responded to God's call with love, hope, and revealed comprehension of the Messiah; they were justified even though they represented future sacrifice only crudely in their holocausts (ExR, IV, 257-258). Their existence proves that those "attracted by divine grace" could live under a better law founded "in God's spirit" (in spiritu Dei) and manifest in their trust - fidutia - in the promise.

Once deigning to use the language of the scholastics, Colet affirms that the patriarchs alone maintained the "habit of the just" (justi habitus) in the old law and that they alone earned spiritual life for their faith and hope (ExR, V. 275) - apparently not at all for their works. Abraham and his spiritual, just progeny followed a divine - not human - law whose grace encouraged fiducial adherence to God's pact (pactum) or covenant (fedum) (ExR, IV. 261-2, 265). Their grace-inspired trust and faith in the promise were rewarded with justification and spiritual propagation. ${ }^{11}$

The patriarchs were, however, exceptions to those floundering in what Colet calls a dark, lapsed "sea of iniquity." "Ignorant of life" and perverse in will, most failed to respond to God's call; instead, they constructed foolish and iniquitous laws to serve their corrupt appetites rather than God's will (ExR, IV. 258-259). Unlike scholastic rational law, human law for Colet is intimately related to idolatrous religion and the paradox of unjust justice, "derived neither from God nor for God" (ExR, IV. 258-259). As Colet explains in his comment upon Romans $5: 12-14$, before Christ only the patriarchs were exempt from the spiritual "death" resulting by Adam's transgression of law. Yet even the patriarchs remained "subject to original sin (peccato originale)," therein resembling Adam, "that corrupt, rugged branch" (ExR, V. 275 on Rom. 5 : 14). ${ }^{12}$ Unlike Erasmus, who thought Adam's fall constituted a pattern for sin, Colet saw original sin as a universal, inherited trait that destroys obedience to God's law. ${ }^{13}$

As the patriarchs demonstrate, however, the effects of the fall admit of reformation. Colet holds that after Adam and the onset of original sin all had the potential to arrive at divine law through conscience, a "certain innate rule of living," even if few succeeded in overcoming the perversity of their nature. Colet holds that this lex innata was strengthened by Mosaic law, that "reminder of conscience" (admonitrix conscientiae) which amplified and codified what was innate. Innate or Mosaic, Colet affirms that pre-Christian 
law is "nothing other than a lucid principle (ratio) for discerning equity and iniquity; condemning this, approving that" (ExR, II. 218-219 on Rom. 2 : 12) ${ }^{14}$ Even though both Gentile and Jew had access to innate principles of divine law, those under Mosaic law performed works without interior fidutia and the Gentiles erred in performing works without a "simple and true" (simplex et vera) conscience. Both groups failed in general to recover the "rule of reason" (dictamen rationis) weakened by the fall. Colet concludes that, in the postlapsarian world, God alone may judge conscience truly, as Paul attests (ExR, II. 219-220; cf. 1 Cor. 4 : 4-5). ${ }^{15}$

Colet follows Paul's view that Mosaic law was essentially "good and holy" (ExR, IV. 262; cf. Rom. $7: 7$ ) though "rough and unfinished" since it was designed for those ignorant of spirituality. It tried to educate sinners about sin but lacked the motivating power of the Spirit. After the sons of the Hebrew patriarchs degenerated from the simple fidutia and justifying fides of their fathers, God sought to recall them by means of a "widespread grace" contained in laws intended to check carnal appetite. Hence came into existence an effectively punitive law that "threatened death for transgressions"; however, Colet attributes its punitive quality not to God but to its practitioners, who perversely refused to exercise the powers to do good they possessed. Although the Old Testament provided the "letter" of the law to the Jews, it did not offer the "more sophisticated and perfect justice" of faith to complete and fulfill the law (ExR, III. 242). Learned Jews had access to the spiritual mysteries contained in cabalistic "oracles," in addition to the letter of the law, yet they still failed to avoid transgressions (ExR, III. 232; cf. I. 213) or choose to possess the interior faith and hope required for justification (ExR, III. 233). ${ }^{16}$

In a passage echoing the spiritual hermeneutics of the Eastern tradition, Colet observes that the carnal Jews worshipped "in an observance of the sensible" rather than "in the mind (mentem) and spirit (spiritum) of the law" and that they refused to live according to law's "spiritual sense" (sensus spiritalem) (ExR, II. 219). It is only the latter, Colet continues, which offers justification. Quoting Romans $7: 14$, Colet affirms that the "law is spiritual" and explains, "that is, it has a spiritual understanding (intellectum spiritalem)." Hence, the Jews had law but failed to perceive its internal sense or to achieve the interior condition and action which constitute justification. On Abraham's model, then, Colet establishes spiritual action as the true "work of the law," expressing what is "mental and spiritual" (mentale et spiritale) (ExR, II. 219 on Rom. 2: 15). ${ }^{17}$ 
Colet recognizes that scriptural references to "law" sometimes designate only the Pentateuch, sometimes the prophetic books as well; but in either sense he affirms without qualification law in its punitive aspect "pertains to the Jews" (ExR, III. 238). Unlike Luther, Colet follows the traditional interpretation of Romans $3: 20$, so that "works of the law" which cannot justify refer primarily to those under Mosaic law (ExR, III. 238-239). ${ }^{18}$ Unable to effect man's reformation in justice, Mosaic law provided "wisdom," but that wisdom, like the Gentiles', was insufficient to produce good action. ${ }^{19}$

By appealing to the contrast between religious eras, Colet outlines the theoretical shape of Christian law. Through Christ's incarnation and redemption, the new "law of faith" (lex fidei) fulfilled the fiducial promise and pactum. It offered a more immediate source of grace, and it resulted in a corresponding increase in the number of the "faithful." This fulfilled law begins in interior faith and leads to perfection in works arising from charity; it provides a moral rule of living which Colet, similar to Erasmus, calls the secta et philosophatio Christi (ExR, IV 248). ${ }^{20}$ At one place, Colet distinguishes among three orders of law: 1) the law of corrupt nature, 2) the law of God recalling humanity to Christ (i.e., the fiducial law), and 3) the perfecting law of God in Christ - the law appropriate to the corporate community of the mystical body (ExR, IV. 264). Ideally, this new, positive law ought to permit libertas in spiritual matters because it replaces Mosaic rigidity with counsel and exhortation (ExR, IV. 264; CC, VII. 168-190). Christian law completes the Hebrew patriarchs' seminal fidutia with Christ's "redemption and consummate justification" (ExR, IV. 262).

The lines of contrast between Mosaic and Christian law become more complicated when Colet considers real-life applications of law in the Christian era. Subjunctive verbs recur tellingly when he describes the legal codes which ecclesiasts should follow. Colet argues that "prudent bishops" (prudentes pontifices) should supplement the lex fidei with statutes and decrees intended to maintain men in grace. These regulations, constituting "pontifical and canonic law" founded on Christ's exemplar, should in theory set down a unified, positive "rule of living" (regulam vivendi) for salvation within the corporate community of the church. This rule should "prescribe," not "prohibit" (ExR, IV. 263), but Colet criticizes the contemporary church, whose excessive punishments depart from the ideal. Unlike negative Mosaic law, canon law, which ought to be positive only, will produce good action in charity among those who have been justified by faith (Hac credentes justificantur, ut bene agant in charitate, IV. 261, 262-3). ${ }^{21}$ With Christ's 
evangelical law in the gospels, canon law should represent "perfect" divine law, unlike its "mixed" and imperfect Mosaic counterpart.

In the Romans Expositio, Colet concludes his digression by asserting that Christians' adherence to their "one" law overrides the binding power of civil and human law since these are based only on fallen reason, the "enemy of grace" (adversaria graciae). ${ }^{22}$ Municipal law, which he describes as the law of "laughable opinions" (ridiculae sententiae) in its judgment of worldly disputes, ought to be "booed and hissed" in the church of God, which follows a "law of faith and charity." Moreover, the "law of kings" (jus regni), unless founded on divine, Christian law, leads the church "into captivity," echoing in the body politic the tyrannical law which Paul found in his members (ExR, IV. 263; cf. Rom. $7: 23$ ). Although in a second work on Romans, the Enarrationes, Colet heeds Paul's advice to pay tribute to and honor political authority (Rom. $13: 7$ ) and holds to the traditional view that temporal rulers are "ministers" of God who receive their authority for acting well or ill as cooperators with God and his providence (ER, XIII. 202), he still does not suggest that submission to political authority absolves the church from seeking to improve government through persuasion. ${ }^{23}$ Indeed, the Expositio's first chapter recalls the Convocation Sermon in its attacks on bishops who subordinate themselves as "slaves" to kings rather than Christ.

Colet put his principles to the test when he spoke out against Bishop Richard Fitzjames and publicly criticized Henry VIII's military adventurism. ${ }^{24}$ In the Romans Enarratio, Colet advances the humanist argument that undermining and opposing political authority through violence is less effective than moving it to virtuous conduct through persuasion. Insofar as a government is evil, it should, Colet affirms with Paul, be overcome with "good," founded in the power of love, not with more evil (Rom. 12 : 17-21). Like Augustine, Colet shares a vision of an evolving secular community based in the principles of Christianity - an explicitly Christian version of Hythloday's Utopia, with the Utopians' rationality supplanted by response to God's call rooted in fiducial hope, faith, and charity. According to Colet, peace ought to reign between Christians and temporal "ministers of God," and both groups ought to be persuaded to seek their common good in creating a divine rather than merely human "commonwealth," the Christian res publica of re-formed humanity acting in charity to embody the "celestial Jerusalem." 25 Something like de Chardin, Colet envisions a continuous growth in the community of the faithful "throughout the entire orb of the earth" until all burn with amor and charitas in an apocalyptic realization of 
the earthly and heavenly paradise (ER, XIII. 204-205); for Colet, the pilgrim church seems potentially identical with its heavenly counterpart. ${ }^{26}$

To achieve this civil, social, and spiritual perfection, Colet insists in the Expositio that "no other law ought to be heard [among Christians] than the divine law through Christ," that is, the "law of charity" (lex charitatis) which adds to the lex fidei the action of the community, the body of Christ cooperating with God's Spirit. In this ecclesiastical, canonic, charitable law, bishops ideally have "indulged the weak, set good limits, and excommunicated transgressors and [those] dead [in faith]" (ExR, IV. 263). ${ }^{27}$ According to Colet, Christianity's faithful and charitable law should not be administered rigidly due to the variety of capacities it comprehends; on the model of Paul, who rhetorically modulates praise and blame, the church should accommodate weakness first through mercy. ${ }^{28}$ Following Dionysian hierarchic principles, Colet asserts that law ought to be applied with proportionate force according to spiritual strength and weakness.

In the Expositio, Colet describes this proportionality by means of an analogy: the church constitutes the area of a circle centered in Christ. The circle's outermost edge refers to the limit of justification, beyond which exists precept only. Inscribed within the outer circle is another, which represents the lowest degree of priestly "precept," whose boundary is relatively close to Christ. Between the outer and inner circles, and between the inner circle and the center, are varying degrees of laity and priests, more or less proximate to the center. For the laity, the outermost circle constitutes precepts whose "transgressors" are excommunicated from Christ's law. For the clergy, the inner circle constitutes precepts implied by their special vows, and these likewise may not be violated without excommunication. In determining violations of legal precepts outside the circles, the church shares the negative legal function of Mosaic Law. But to those close to and within the circles, the church offers "counsels" designed to draw the faithful nearer to Christ. Such counsels constitute the "positive" law peculiar to Christianity. Through them, the church offers varied degrees of praise according to each member's capacity. It "approves of (probat) those who observe the circumference of precepts; it praises (laudet) those who strive towards Christ; it admires (admiratur) those who have been perfected in the center itself" (ExR, IV. 264). Beyond precept, Colet indicates, there is sin. Within precept, there is indulgence for those who fall and praise to act better. ${ }^{29}$ Despite the indulgence for sin within the limits of precept - a point developed at length in the Commentary on 1 Corinthians - the Expositio, influenced by Paul's admonitions against apostasy (Heb. $6: 4-8$ ), cautions that those who have received 
counsels and have professed to follow them must carry them out. To fail to do so is to move backwards to the circumference of Christianity (ExR, IV. 264). ${ }^{30}$

For Colet, the interior life of the Christian is centered on a principle of struggle for higher levels of perfection, yet within Christian society strife for perfection should be expressed through charitable cooperation; Colet decries litigious sorts who carry disputes motivated by avarice to civil law. ${ }^{31}$ To the contrary, Christians should strive to exist in the freedom of counsel against the pull of enslaving precept, and they should heed voluntarily the compelling, sweet, natural, and attractive call of grace. Colet asserts that the Christian brought into spiritual being (esse) through fidutia becomes illuminated through faith and perfected by love of God and the expression of that love outwards through works in the world; works, in turn, constitute a means of cooperation with God's Spirit in the completion of providence. Colet follows Augustine in shifting the question from whether humanity may choose to fulfill providence and predestination to whether humankind freely does choose to act in charity with the Spirit as co-creator and coefficient cause of God's spiritual society (CC, XIII. 258-63).

For Colet, humanity may voluntarily imitate and participate in God's love as co-creative beings. In perfection, which Colet identifies with charity, one loves as one is loved by God (CC, XIII. 258) and therefore enervated by the Spirit for the increase of the church. Although Paul's texts sometimes sway Colet to stronger predestinarian stands, his longer digressions, as on Romans 12 and 1 Corinthians 12 and 13, drift to notions of Christian operatio and cooperatio with God in society. Colet conceives of the possibility of human liberty within Christian law, and he looks to the fulfillment of that potential in act. Foreshadowing the dilemma of Milton's Satan, freedom consists in the choice to cooperate with God or to be enslaved unwillingly to the dictates of providence. ${ }^{32}$ One who freely chooses participation in the Christian community, a Christian in the lex charitatis, works willingly for the completion of unity of the whole and the transformation of the corporeal church into its fully spiritual successor.

In his view of law, Colet maintains the broad outlines of the pactum theology of the via moderna, but he brings his theology close to continental Neoplatonism in its description of the action of the Christian social organism and, at the same time, close to the theology of the devotio moderna and the Reformation it its stress on the priority of grace and interior faith in justification. He directs his theology not to the elaboration of an empty ontological order, as John B. Gleason has claimed, but to the description of a spiritual 
actio and ratio vivendi focused on the means of acting authentically in the world with the purpose of realizing a perfected and transformed world. ${ }^{33}$

\section{II}

The distinctive nuances of Colet's theory of law emerge when one examines it in relation to contemporary views. Colet never arrives at the clarity of Luther's two "kingdoms," secular and ecclesiastic, but his assertion of the primacy of the positive law of Christianity, built upon counsel rather than precept, approaches Luther's notion of the unique, extra-legal nature of Christian government worked out in the 1520 s.

Like Colet, Luther considered the truly Christian society as beyond the negative and punitive force of law, a view he clarified in his 1523 treatise on secular authority, Von weltlicher Oberkeit:

If all the world were composed of real Christians, that is, true believers, there would be no need for or benefits from prince, king, lord, sword, or law. They would serve no purpose, since Christians have in their heart the Holy Spirit, who both teaches and makes them to do injustice to no one, to love everyone, and to suffer injustice and even death willingly and cheerfully at the hands of anyone. When there is nothing but the unadulterated doing of right and bearing of wrong, there is no need for any suit, litigation, court, judge, penalty, law, or sword. For this reason it is impossible that the temporal sword and law should find any work to do among Christians, since they do of their own accord much more than all laws and teachings can demand. ${ }^{34}$

Like Colet also, Luther conceives of an ideal Christian society as lacking the punitive character of human law. For Luther, the rule of the church ought to remain essentially distinct from secular world, uncontaminated by the perverse human force of sword and law. ${ }^{35}$ In principle, Luther would agree with Colet that "every action within the church ought should imitate [Christ's] so that there might be nothing within it save what exists more truly in him; nor should there be in the church anything save what may be derived from his truth." 36 But Luther and Colet differ substantially on the means of applying this principle to the real world. Luther frankly realizes the impossibility of achieving an ideal church universally composed of true Christians: like the wild beast restrained by chains and ropes, God subjects the non-Christian majority "to the sword so that, even though they would like to, they are unable to practice their wickedness, and if they do practice it they cannot do so without fear or with success and impunity." 37 Given his convic- 
tion that most of humanity is essentially corrupt, Luther harbors no illusions that an ideal church may be realized: "it is out of the question that there should be a common Christian government over the whole world, or indeed over a single country or any considerable body of people, for the wicked always outnumber the good." 38 Therefore, for Luther, the Christian must recognize that civil authority offers a necessary control over the necessarily evil majority; it offers a power parallel to that of the church but distinct from it. As the gospels enjoin, Christians must accept civil authority and law although its precepts will always be surpassed by the Christian, supra-legal virtue practiced by the faithful few.

As I indicate above, Colet pays lip service to the power of secular authority, but his submission is tentative and temporary since he, unlike Luther, envisions an era when the circle of Christianity will enlarge to encompass all. His conviction in the potential for human perfection despite weakness leads Colet to frame statements that have since seemed puritanical to some: "Even if the Apostle in the first epistle to the Corinthians conceded carnal procreation to human weakness, out of necessity rather than [Paul's] genuine desire, it is still no matter for Christ: nor is it necessarily required for his proliferation within Christianity even if it is necessarily permitted to the soft and infirm. For it is the substance of created humanity leading to damnation, not of re-created humanity in Christ leading to salvation." 39 Colet recognizes that an ideally spiritual society is unlikely to appear in the near future thanks to the procreative capacities of non-Christians and those Christian in name only: "Nor was it to be feared lest all the pagan world should be Christianized: since even now the greatest part of humanity, even that under the name of Christianity, paganizes it." 40 Although he admits the need for indulgence of the weak in the real world, he holds unflinchingly to the principle that Christians ought not indulge in carnal matters if they can refrain: "[Paul] recognizes all within the church should be celibate following Christ's example, yet at the same times he sees that all are not able" (my emphasis). ${ }^{41}$ Colet here applies the principle of indulgence which in the Expositio he had granted to Christians within the circle of faith. The issue becomes focussed on ideal principle and exhortation rather than application of fixed law. Colet believes that a new age of universal Christendom, when the temporal church may replace law with counsel, punishment with praise, will result from the apostolic evangelization of the world, what Colet calls a "spiritual procreation" carried out by those knowledgeable in the true, spiritual sacrament of marriage, holy orders. At its conclusion, Colet's ideal world would be brought fully under canonic "law," which establishes the outer limits of spiritual 
existence but which regulates behavior not by rule but by counsel, indulgence, and exhortation. Like Luther, Colet sees in genuinely practiced Christianity the limits of law and the foundation of liberty and free, spiritually motivated act; unlike Luther, he maintains the drawing of all humanity within the circumference of Christian rule as the end of providence.

Conversely, his distrust of secular law leads Colet to assert forcefully in the Convocation Sermon that no need for new law exists even in an imperfect world; rather, genuine enforcement of existing law and living according to Christianity's rigorous spiritual standards should more than suffice as means of controlling the populace. What is needed instead, Colet tells the bishops, is a top-down actualization of the Christian life wherein issues of legality, such as that concerning the privilege of sanctuary, are subordinated to an internal state of spirituality:

Ye wyll haue the churches liberte, and nat be drawen afore secular iuges: and that also is ryght. ... But if ye desire this liberte, first vnlouse your selfe frome the worldlye bondage, and from the seruices of men; and lyfte vp your selfe in to the trewe lybertie, the spirituall lybertye of Christe, in to grace frome synnes; and serue you God, and raygne in hym. And than, beleue me, the people wyll nat touche the anoynted of theyr Lorde God. ${ }^{42}$

If the rule of the religious were truly to displace the secular law in this ideal, Christian res publica, existing political institutions would lose their purpose and be recognized as the products of lapsed reason and will. This challenge to secular authority seems to have motivated Colet's bolder pronouncements against sword and civil law. ${ }^{43}$ Moreover, it helps to explain both Colet's apparent willingness in 1511 to judge matters of heresy on an ecclesiastical court commissioned by Archbishop Warham, thereby supporting the authority of canon law in establishing the limits of precept, and his alliance with Wolsey in bringing ecclesiastical influence more fully to bear on civil government through the exercise of ecclesiastical authority in the chancellorship. ${ }^{44}$ Between December 1515 and June 1517, also, Colet held a place on the King's Royal Council apparently through the assistance of Wolsey, forming, as Gleason surmises, part of a reforming group who sought to advance ecclesiastical authority by means of its association with secular government. ${ }^{45}$ Given Colet's repeated assertions of the priority of ecclesiastical relative to civil law, one may easily imagine the idealist Colet taken with Wolsey's early assertions of ecclesiastical power. 
One senses a profound gulf between Colet and Thomas More on the issue of ecclesiastical and secular power and law. Although there is no record of conflict disturbing their early friendship and there is strong evidence to support their shared criticisms of existing courts and corresponding idealism, the evidence points to distinct views of civil law, particularly as the conflict and polemic of the Reformation sharpen. In a sense, Colet was fortunate to have died in 1519, shortly after Luther's posting of the ninety-five theses and two years before the publication of Henry VIII's Assertio septem sacramentorum; he escaped the sequence of events which led to More's anguish of church and state.

In 1519 More had only a superficial knowledge of Luther and his reforms based on incomplete reports and a few books sent to him by Erasmus. ${ }^{46}$ As More wrote and revised his Responsio to Luther's defense, Contra Henricium (1522), he seems to have tempered whatever idealism he had formerly toyed with in Utopia through a solid dose of ecclesiastical and political reality. ${ }^{47}$ Although his motives for writing the Responsio remain uncertain, it is impossible to imagine that pressures from English authorities, including Henry, played no part in his decision. More is only beginning his public career in the year of Colet's death, 1519 , but he already had committed himself to public service, following his training in common law. Colet likely would temper the implications of his assertions in the Expositio regarding secular law, especially in the case of More, and Colet's own service on the Royal Council may have softened his earlier views on the evils of human law, but it seems likely that Colet would have felt reservations about a career like More's, predicated on the necessity and utility of secular law and personal adnvancement. Moreover, one senses that Colet, had he lived, may have felt closer to Luther than to More, particularly given the latter's defense of civil law in the Responsio.

It is hard to imagine Colet, who forswore the need for protection of meum et teum in Christian society, agreeing with More's argument attacking Luther's dismissal of law and preference for judgment derived from the Christian magistrate. For his part, More speaks with the professional demeanor of one trained in common law when he argues for the utility of "established law":

For the law of the gospel does not apportion possessions, nor does reason alone prescribe the forms of determining property, unless reason is attended by an agreement, and this is a public agreement in the common form of mutual commerce, which agreement, either taking root in usage or expressed in writing, is public law. ${ }^{48}$ 
For Colet and Luther, both lacking More's confidence in rational arbitration of disputes, any "public agreement" is tainted by the corruption of a lapsed "public" and hence is suspect. For Colet, the solution to the problem of appropriate control is the rule of canon law over all human action, this law seen not in the letter but its spiritual sense as leading to perfect action. For Luther, the solution is the division of law according to two kingdoms, the secular forming a means of suppressing the chaos of a non-Christian world and the Christian as a means of fostering faith and conscience in an individual's vocation. More anticipates such attacks on the spiritual utility of law by arguing for the necessity of some law, whatever its precise form:

the human law which alone apportions ownership of goods binds Christians; if this ownership is done away with, there cannot indeed be stealing. But if [Luther] should say from this premise the argument is drawn that we would do better without that law from which the ownership of goods arises and would do better to live in a certain natural community with the occasion of stealing eliminated, it does not help his case even if someone should grant him this argument. For even if we could live in common with far fewer laws, we still could not live altogether without laws. For the obligation to work would have to be prescribed for certain classes, and laws would be needed to restrain crimes which would run riot in that kind of life. ${ }^{49}$

In the pragmatic context of his debate with Luther, More can no longer afford to present a Utopian "natural community" - the "even if we could" rings with doubt. More undercuts Luther's ideal notion of the true Christian and Colet's idealized Christian society by asserting that human nature, left to its own devices, will "run riot." For More in the 1520 s, law becomes a restraint on perverse human conduct; Luther will later attribute this constraining purpose of secular law only to those without faith.

More is also uncomfortable with the legal implications of predestinarian views like Luther's: in A Dialogue Concerning Heresies, written in 1531, he argues that the Lutheran conviction in predestination gives rise to indifference to law:

therefore all lawes [those who believe in predestination] sette at nought. And they holde that no man is bounded to obaye any but wolde be at lybertye to byleue what they lyste and doo what they lyste as they saye that god dothe with vs not what we deserue but what hym selfe lyste. ${ }^{50}$ 
Here, liberty becomes a threat to religious and secular order, a threat, More seems to feel, that must be paradoxically constrained even in the Christian era by the legal force of consensus, the accretion of ecclesiastical authority through scripture, councils, and religious custom. Before the sharpening of such positions, Colet asserts that Christians within the circumference of faith act cooperatively in response to their inward attraction to Christ and his corporate representative, the church.

More sees the church as a corporate structure, a social community built from a shared past, a shared faith, and shared hopes. Colet remains close to Luther in holding foremost to a faith rooted in the individual; although unlike Luther he retains an important place for the spiritual authority of canon law, the hierarchy, and the corporate body of the church, Colet places these external considerations in a subordinate position relative to the interior condition of faith. Colet envisions a progressive realization of an Augustinian, earthly Jerusalem extending in liberty out from the fiducially purified, faithful, and charitable Christian, striving beyond secular law, to an actualized Christian community; ironically, the seeds of reform which would ensure the destruction of his idealistic vision were already coming to fruition on the continent and, soon enough, in England itself.

\section{Southwest Texas State University}

\section{Notes}

1. See Alister E. McGrath, "Iustitia Dei": A History of the Christian Doctrine of Justification (Cambridge: UP, 1986), I, 180-187; II. 1-3, on the difficulties of relying on key texts alone for views of justification. In this paper, references to Colet's works will refer to the following editions and employ the following acronyms parenthetically in the text: the Romans Expositio (ExR; in Opuscula Quaedam Theologica, ed. J. H. Lupton [London, 1876; rpt. 1966]); the Romans Enarratio (ER), ed. J. H. Lupton (London, 1873; rpt. 1966); the 1 Corinthians Commentaria (CC), ed. Bernard O'Kelley and C. A. L. Jarrott (Binghamton, NY: Medieval \& Renaissance Texts and Studies, 1985); and the Dionysian treatises (CH, EH) and De Sacramentis Ecclesiae (SE), ed. and trans. by John B. Gleason, Appendix I in John Colet (Berkeley: University of California Press, 1989).

2. McGrath, I. 166-179.

3. McGrath, I. 155-87.

4. Allen, Op. Ep., IV. 515: "In utriusque iuris libris erat non indiligenter versatus. Denique nullus erat liber, historiam aut constitutiones continens maiorum, quem ille non euoluerat." Gleason speculates that Colet studied law at Orleans with Francois Deloynes in 1494 (60).

5. McGrath, I. 27-28. 
6. Lupton, Opuscula quaedam theologica, p. 137, n. 1, indicates a verbal similarity between Erasmus's annotation on Rom. 1. 17 and the Expositio, IV, pp. 161-162, the significance of this passage deserves consideration. Colet's passage fills in some of the ambiguity of Colet's definition of faith at III. 230-231 (on this ambiguity, see Jarrott, "Erasmus's Annotations," pp. 127-128). In particular, it demonstrates that Colet recognized the distinction between God's faith and man's (the former, rather ironically, fulfilling the Ciceronian definition of "faith"), and within man's, between faith as

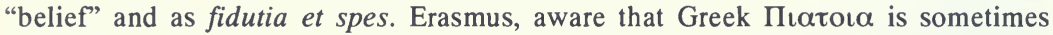
translated "improperly" in the Vulgate, nevertheless uses both fides and fidutia nearly interchangeably, like Colet: see John B. Payne, "Erasmus: Interpreter of Romans," Sixteenth Century Essays and Studies, 2 (1971), 21. In an addition to the 1527 edition of the Novum Instrumentum, Erasmus uses the same three-fold sense of faith developed here by Colet. See Rabil, pp. 143-144; John B. Payne, "The Significance of Lutheranizing Changes in Erasmus's Interpretation of Paul's Letters to the Romans and Galatians in his Annotationes (1527) and Paraphrases (1532)," in Histoire de l'exégèse au XVIe siècle, ed. O. Fatio and P. Fraenkel (Geneva: Droz, 1978), p. 318. Payne claims that in the addition, Erasmus is "apparently attempting to make a clarifying contribution to the debate concerning this subject in the late 1520's," and thus responding to emerging Protestant positions on faith. If this were true, it is significant that he should turn back to the broadened definition of faith which Colet writes in the Expositio: perhaps Erasmus sought a more ready means of moving from faith to hope and charity.

7. Cf. Calvin's Institutes, I. 10. 2; II. 7-8, 10. 1, 7, on the role of law; Aquinas, Summa Theologiae, II-II q. 66 a. 8. For a comparison of the views of natural law in Aquinas and Biel, see John L. Farthing, Thomas Aquinas and Gabriel Biel: Interpretations on St. Thomas Aquinas in German Nominalism on the Eve of the Reformation (Durham: Duke University Press, 1988), 72-75.

8. See Trinkaus, In the Image and Likeness of God (Chicago: University of Chicago Press, 1972) I. 181-183, 393-394, n. 8, on Augustine's De Trinitate, books IX-XII. On Colet's interest in and modification of these faculties, see Sears Jayne, John Colet and Marsilio Ficino (Oxford: Oxford University Press, 1963), 56-76.

9. ExR, IV. 257: "Homo transgressor divinae legis, destitutus multa gracia, ex alto et salubri illo loco, ubi vivitur eterniter, pulsus in hanc vallem contagiosam et pestilentem, misere degit morbidus et moriens omni hora. In pessima hac regione obliquatur voluntas, obtenebratur intellectus, infirmatur memoria, appetitiones carnis inflammantur, morborum et mortis causae, tum corporum tum animarum, infinitae sunt." The topos of man's postlapsarian misery received emphasis similar to Colet's in Poggio Bracciolini's Two Books on the Misery of the Human Condition (1455) (Trinkaus, I. 258-270).

10. Summa Theologica, II. i. Q. 91. A. 3-4.

11. Peter Iver Kaufman, Augustinian Piety and Catholic Reform (Macon, Ga.: Mercer University Press, 1982), p. 73, citing SE, 89-91.

12. Lupton's translation (Opus., 156-157) suggests that Colet excluded the patriarchs from original sin: "though all that had lived besides them were under the law of original sin" (my emphasis). Colet's Latin is ambiguous: "etsi qui fuerant preterea omnes fuerant 
obnoxii peccato originali" (ExR, V. 275). Preterea is properly an adverb rather than a preposition, so that a truer translation would read: "Notwithstanding [the 'just habit' of the patriarchs] those who existed hereafter [i.e., after Adam's sin] were all subject to original sin." This would accord more with Colet's discussion of the role of grace in "attracting" the patriarchs above the flood of sins in the postlapsarian world. Moreover, this translation would follow Origen's point that all - even Abel, Enoch, Methusela and Noah - sinned through Adam; see Karl Hermann Schelkle, Paulus Lehrer der Vaeter: Die altkirchliche Auslegung von Romer 1-11 (Dusseldorf: Patmos, 1956), 163-164.

13. ExR, V. 275: "Ut tota arbor in radice est, et totus homo in semine; ita universum genus humanum erat in Adam; in quo tota natura peccavit ad mortem." On Erasmus, see John B. Payne, "Erasmus: Interpreter of Romans," Sixteenth Century Essays and Studies [Sixteenth Century Journal], 2 [1971], 12-14; C. A. L. Jarrott, "Erasmus's Annotations and Colet's Commentaries on Paul," in Essays on the Works of Erasmus, ed. Robert L. deMolen [New Haven: Yale University Press, 1978), 129-131; Albert Rabil, "Erasmus's Paraphrases of the New Testament, in Essays on the Works of Erasmus, 147-148). See Erasmus's long note on Romans 5:12 in Op. Om., VI. 585-590.

14. Beginning with Chrysostom, Homily V on Romans 2:15-16 (tr. Philip Schaffe, Homilies on Romans [Select Library of the Nicene and Post-Nicene Fathers; New York: Christian Lit. Co., 1889], XI. 265-266), conscience had frequently been associated with the Gentiles' "natural law." See Trinkaus (II. 749-751) on Ficino's interpretation of "innate law" as conscience. Colet restricts the autonomy of innate law by limiting those who possess a "true and simple" conscience to only a few. The notion of conscience as innate law subject to change and error had developed in late scholasticism; see Heiko A. Oberman, The Harvest of Medieval Theology (Cambridge, Mass.: Harvard University Press, 1963), 65-67; Michael G. Baylor, Action and Person: Conscience in Late Scholasticism and the Young Luther (Leiden: Brill, 1977), 20-118.

15. McGrath, I. 157-79.

16. Cf. Colet on cabalistic Jewish spirituality in EH, V. i. 238; for its relation to Origen, see Maurice Wiles, The Divine Apostle: The Interpretation of St. Paul's Epistles in the Early Church (Cambridge: Cambridge University Press, 1967), 64-65. Payne, "Erasmus: Interpreter," 17.

17. Kaufman, Augustinian Piety, refers to this "spiritual infusion of form" as a "moral transvaluation" revealed in act (76).

18. Erasmus's Annotations exhibit a similar understanding of "law" as especially applicable to ceremonial, Mosaic, carnal law (Payne, "Erasmus: Interpreter," pp. 19,22-23). Both Colet and Erasmus differ from Luther, who denies the efficacy of all works; see Luther's Works: Lectures on Romans, ed. H. C. Oswald, XXV. 241-242 on Rom. 3:20. Payne notes that the identification of works with ceremonial law begins with Origen and the Ambrosiaster (19-20).

19. ExR, III. 239: “Lex magistra erat pedagogus; jubens bonum et prohibens malum, sed non potentes observare. Per legem ergo Judei magis sapientes erant quam boni: per graciam vero omnes boni quam sapientes." Cf. Gal. 3:24-25. The contrast between justification in law and in faith is a crucial one for Colet, as well as for other theologians. 
Erasmus's Paraphrase on Romans 1:17 distinguishes justice ex fide from the legales Indaeorum ceremoniae in that the former surpasses the latter $(\mathrm{Op} . \mathrm{Om}$., VII. 781B; cited by Payne, "Erasmus: Interpreter," 19, n.101). Colet's view of the efficacy of works is distinct from Luther's (Kaufman, Augustinian Piety, 68-72).

20. ExR, IV. 248: "Deus enim spiritus est spiritificans, apud quem nihil adest nisi fides habita Jesu, et expectatio premii, et in expectatione amabilis operatio: - 'haec tria, sed major horum charitas' (1 Cor. 13:13) et imitatio Iesu. ... Haec secta Christi et philosophatio non tantum est verbis quam re, operibus, et vita ipsa. Et fides justificans importat insuo significatu imitationem Christi, et cooperationem cum illo, quam alibi vocat Paulus 'fidem quae per dilectionem operatur' (Gal. 5:6). Is censetur sperare in Deo et credere in Christo, qui operatur in Spiritu sancto." Jarrott, 135, notes the agreement of Colet and Erasmus on the philosophy of Christ as essentially moral. Cf. Erasmus's Paraclesis, tr. J. C. Olin in Christian Humanism and the Reformation (New York: Fordham University Press, 1975, 2nd ed.), 99: "If it happens that they [princes, bishops, and teachers], having laid aside their own affairs, should sincerely cooperate in Christ, we would certainly see in not so many years a true and, as Paul says, a genuine race of Christians everywhere emerge, a people who would restore the philosophy of Christ not in ceremonies alone and in syllogistic propositions but in the heart itself and in the whole life."

21. Here, "positive" law is apparently related to posuerunt by Colet for etymological illustration. Lupton, Opus., 139, n. 1, observes that "positive" law generally refers to "all beyond the law of Nature," both human and divine. However, in Aquinas, Sum. Theol., XCV.ii, positive law is specifically equated with human law and conceived as particular legal applications of the general principles of natural law. Colet classifies positive law - true human law - as a subspecies of divine law, distinct from "natural" and "human" law.

22. In a comment on Romans 13, Colet agrees with Paul on Christians' need to submit to secular law (ER, XIII. 198-204). Yet this ought not to negate the seriousness of his charges against rational law. His description of the latter as an "adversay" of grace recalls his earlier identification of Satan as the "adversary" of divine law (ExR, IV. 256).

23. Cf. Kaufman, "Polytique Churche," 84.

24. Both events are recounted by Erasmus in his letter to Jodocus Jonas. See Vies de Jean Vitrier et de John Colet, tr. and ed. by André Godin (Angers: Editions Moreana, n. d. [1982], 74-82; Kaufman, "Polytique Churche," 66-68. Gleason speculates that Colet's views in the Expositio are shaped by contemporary events surrounding the clerical prosecution of Richard Hunne (85-90), though the association and subsequent chronology remain tentative; see 255-258 regarding Colet's "climactic scene" with Henry VIII.

25. Augustine is less idealistic in his explanation of the relation between governors and Christianity, defining their existence in the pilgrim church as governed by a sense of duty and love of mercy rather than the active performance of charitas (De civitate dei, XXIX. 14). 
26. See Kaufman, Augustinian Piety, 105-110, on the relation of Colet's "city of God" to his theology; cf. De civitate dei. XVIII, 54; XIX, 5-12.

27. Christopher Harper-Bill, "Dean Colet's Convocation Sermon and the Pre-Reformation Church in England," History 73 (1988), 191-210, argues that many of Colet's criticisms of the contemporary church are not borne out by evidence; however, Harper-Bill concludes Colet's perception of the dangers of "tensions within the higher echelons of the English church" is more accurate (208-209).

28. In The "Polytique Churche," Kaufman states that Colet "bragged that pontifical decrees and canonical statutes ... generated the only standards by which the Christian life could be measured and the clergy and church reformed" (79); although Colet sees the institutional church as a source of true law, he here assumes that the church is an ideal one working with the Spirit. Colet's criticisms of abuses of laws within the church belie his acceptance of the ecclesia; along similar lines, Gleason argues that Colet usually supported institutional ecclesiastical hierarchy as reflected in his support of Wolsey (245-252).

29. Alluding to some few passages in Colet's treatises on the Dionysian hierarchies, Gleason concludes that for Colet "the Christian ... must renounce this world and its business and follow Christ without ceasing or looking back. If he fails on this high level he has no fallback position - he fails completely" (191). This conclusion oversimplifies Colet's position, as do Gleason's subsequent claims regarding Colet's "absolutist terms" (192).

30. Gleason (190-191) does not note that Colet directs this assertion specifically at those who have taken vows; despite his rhetorical exhortation in passages directed at clerical abuse, his views toward the laity are generally more accommodating; see for example ER, XV. 221-222.

31. Kaufman, Augustinian Piety, 77-78, 107; "Polytique Churche," 79.

32. Kaufman, Augustinian Piety, 76-77.

33. Gleason concludes that "For Colet structure was primary, and ordo was tied to hierarchia.... Everything, for Colet, had to have its fixed place" (265). See, however, Colet's observation concerning Dionysius' Celestial Hierarchy: "quum in reportatis, et in his quae dedicimus in eo libro, id vel primum et maximum est, ut quicquid aliunde accepimus boni, id benigniter deinceps impartiamus aliis et communicemus" (CH 166).

34. From Temporal Authority: To What Extent It Should Be Obeyed, tr. J. J. Schindel in Luther's Works (LW), ed. Walther I. Brandt (Philadelphia: Muhlenberg Press, 1962), 45. 89; Von weltlicher Oberkeit, D. Martin Luthers Werke: Kritische Gesammtausgabe (WA) (Weimar, 1900), 11. 249-250.

35. LW, 45. 88; WA, 11. 249.

36. De Sacramentis, my translation here and elsewhere unless otherwise cited; the Latin is edited and translated in Gleason, Appendix I, 310: Omnis actio in ecclesia debet esse imitacio illius [Christ's], vt non sit in ea quicquam nisi quod ipsum est in illo verius; nec debet esse in ecclesia nisi quod ab illius veritate deriuetur. 
37. LW, 45. 90; WA, 11. 251.

38. LW, 45. 91; WA, 11. 251-252.

39. Gleason, Appendix I, 310: Carnalis ... generatio, tametsi mollitudini hominum in prima epistola ad Corinth[ios] ab apostolo indulgetur, necessitate magis quam voluntate: tamen ipsa non est res Christi: nec ea nec eius prolificatio in Christianitate requiritur necessario, tametsi necessario mollibus et infirmis permittitur. Est enim illa res hominis creati in damnationem, non recreati hominis in Christo in salutem. See Gleason, 192.

40. Gleason, Appendix I, 310: Nec erat timendum ne tota paganitas christianizet: quum nunc quoque sub ipso nomine christianitatis maxima pars hominum paganizet.

41. Gleason, Appendix I, 312: [Paul] videt omnes in ecclesia ad exemplum christi celebes esse oportere, tamen simul videt omnes non posse.

42. Convocation Sermon, Appendix C in J. H. Lupton, A Life of John Colet (London: Bell, 1887), p. 303.

43. Gleason, pp. $256-260$.

44. Gleason, pp. 239-240, 244-245.

45. P. 248.

46. John M. Headly, introduction to Responsio ad Lutherum, 5/2 in The Complete Works of St. Thomas More (New Haven: Yale University Press, 1969), 781-785.

47. On his earlier idealism, see Kaufman, "Polytique Churche," 75-84. On More's motives for writing the Responsio, see Headley, 790-798; Richard Marius, Thomas More: A Biography (New York: Knopf, 1984), 280.

48. Responsio ad Lutherum, 5/1 in The Complete Works of St. Thomas More, ed. John M. Headley, tr. Sr. Scholastica Mandeville (New Haven: Yale University Press, 1969), 277.

49. Responsio, 275, 277.

50. Vol. 6 in The Complete Works of St. Thomas More, ed. Thomas M. C. Laawler, Germain Marc'hadour, and Richard C. Marius (New Haven: Yale University Press, 1981), 403. 